\title{
KOMUNIKASI RITUAL DALAM UPACARA TAWUR LABUH GENTUH DI TAMAN MAYURA KOTA MATARAM
}

\author{
I Nyoman Buda Asmara Putra ${ }^{1}$ \\ STAHN Mpu Kuturan Singaraja
}

Abstract

Communication is a fundamental need in human life. By communicating, humans interact with God, fellow humans and the natural environment to establish a harmonious life. Hindus in West Nusa Tenggara carry out a tawur labuh gentuh ceremony at Mayura Park, Mataram City implementing the tri hita karana concept. In the process of implementing the tawur labuh gentuh ceremony, communication dynamics occur using symbols that need to be understood together. This study, entitled "Ritual Communication in the Tawur Labuh Gentuh Ceremony in Mayura Park, Mataram City", raises the issue, namely how is the form of ritual communication in the tawur labuh gentuh ceremony in Mayura Park, Mataram City? The general purpose of this research is to broaden scientific insight about ritual communication and provide explanations to various parties regarding the tawur labuh gentuh ceremony so that it can be socialized to the public and to religious institutions in making a policy. Its specific purpose is to describe and analyze the form of ritual communication in the tawur labuh gentuh ceremony in Mayura Park, Mataram City.

This research was conducted using qualitative methods, so that the data analysis was carried out in a descriptive qualitative and interpretative manner. Mayura Park, Mataram City, West Nusa Tenggara Province was chosen as the research location because the tawur labuh gentuh ceremony was held in a large degree for the first time in this place. Besides that, the limited information makes Hindus not all know the procession and the meaning of the ceremony from beginning to end, so it is deemed necessary to conduct research as a reference source. This form of ritual communication in the tawur labuh gentuh ceremony combines two theories used as a scalpel, namely Jurgen Habermas Communicative Action Theory and Charles Sander Pierce's Theory of Communication Semiotics.

\footnotetext{
${ }^{1}$ inyomanbudaasmaraputra29@gmail.com
} 


\section{Keywords Ritual communication, Ceremony, Hinduism and Tawur labuh gentuh}

\section{PENDAHULUAN}

Istilah komunikasi ritual pertama kalinya dicetuskan oleh James W. Carey. la menyebutkan bahwa, "In a ritual definition, communication is linked to terms such as "sharing," "participation," "association," "fellowship," and "the possession of a common faith". Hal ini berarti, dalam perspektif ritual, komunikasi berkaitan dengan berbagi, partisipasi, perkumpulan/ asosiasi, persahabatan, dan kepemilikan akan keyakinan iman yang sama. Selanjutnya ditambahkan Carey, dalam pandangan ritual, komunikasi tidak secara langsung diarahkan untuk menyebarluaskan pesan dalam suatu ruang, namun lebih kepada pemeliharaan suatu komunitas dalam suatu waktu. Komunikasi yang dibangun juga bukanlah sebagai tindakan untuk memberikan informasi melainkan untuk merepresentasi atau menghadirkan kembali kepercayaankepercayaan bersama. Pola komunikasi yang dibangun dalam pandangan ritual adalah sacred ceremony (upacara sakral/suci) dimana setiap orang secara bersama-sama bersekutu dan berkumpul (fellowship and commonality). Dalam pandangan ritual, yang lebih dipentingkan adalah kebersamaan masyarakat.

Kata komunikasi atau communication dalam bahasa Inggris berasal dari kata Latin communis yang berarti "sama", communico, communicatio atau communicare yang berarti "membuat sama" (to make common). Istilah communis paling sering disebut sebagai asal kata komunikasi, yang merupakan akar dari kata Latin lainnya yang mirip. Komunikasi menyarankan bahwa suatu pikiran, suatu makna atau suatu pesan dianut secara sama. Kata lain yang mirip dengan komunikasi adalah komunitas (community) yang juga menekankan kesamaan atau kebersamaan. Tanpa komunikasi tidak akan ada komunitas karena komunitas bergantung pada pengalaman dan emosi bersama dan komunikasi berperan menjelaskan kebersamaan itu (Mulyana, 2012:46).

Ritual dalam Kamus Ilmiah Populer memiliki arti menurut upacara agama; ritus yang berarti upacara suci (keagamaan) tata cara atau tahapan-tahapan dalam upacara keagamaan (Tim Prima Pena, 2006:412). Merujuk pada pendapat Mulyana (2012:2728) mengatakan komunikasi ritual erat kaitannya dengan komunikasi ekspresif yang biasanya dilakukan secara ritual. Suatu komunitas yang sering melakukan upacaraupacara berlainan sepanjang tahun dan sepanjang hidup, yang disebut antropolog sebagai rites of passage, mulai dari upacara kelahiran, sunatan, ulang tahun (menyanyikan happy birthday dan pemotongan kue), pertunangan, pernikahan, hingga upacara kematian. Dalam acara-acara tersebut orang-orang mengucapkan katakata atau menampilkan perilaku-perilaku tertentu yang bersifat simbolik. Ritus-ritus lain seperti berdoa, membaca kitab suci, naik haji, upacara wisuda, perayaan lebaran dan Natal, juga adalah komunikasi ritual. Mereka yang berpartisipasi dalam bentuk komunikasi ritual tersebut menegaskan kembali komitmen mereka kepada tradisi keluarga, suku, bangsa, negara, ideologi, atau agama mereka. Komunikasi ritual adakalanya bersifat mistik dan seringkali perilaku orang- 
orang yang ada di dalam komunitas tersebut sulit dimengerti dan dipahami oleh orangorang yang ada di luar komunitas. Komunikasi ritual ini bisa jadi akan tetap ada sepanjang zaman, karena ia merupakan kebutuhan manusia, meskipun bentuknya berubah-ubah demi pemenuhan kebutuhan dirinya sebagai makhluk individu, anggota komunitas tertentu, makhluk sosial, dan sebagai salah satu bagian dari alam semesta.

Umat Hindu di Nusa Tenggara Barat menjaga keharmonisan alam semesta beserta isinya dengan melaksanakan bhuta yajña, salah satunya adalah upacara tawur pada sasih kesanga. Umat Hindu di Kota Mataram untuk pertama kalinya melaksanakan upacara tawur labuh gentuh di Taman Mayura. Upacara ini bertujuan untuk marisudha gumi atau pembersihan dan penyucian Bumi secara sekala dan niskala. Upacara ini dilaksanakan karena melihat situasi masyarakat di Lombok dan Sumbawa tidak kondusif akibat tindak kekerasan yang terjadi antar warga, begitu juga musibah bencana alam yang merusak tatanan kehidupan masyarakat. Dengan melaksanakan upacara ini umat Hindu di Kota Mataram mengharmoniskan hubungan dengan Tuhan, alam lingkungan, antar sesama manusia dan juga dengan makhluk yang tingkatannya di bawah manusia. Upacara tawur labuh gentuh merupakan salah satu tingkatan tawur agung yang sudah barang tentu memerlukan komunikasi yang efektif di dalam pelaksanaannya sehingga tercipta suatu pemahaman yang sama antar umat Hindu mengenai esensi upacara ini baik dari segi tattwa, susila dan acaranya.

Penelitian ini mengkaji bentuk komunikasi ritual dalam upacara tawur labuh gentuh di Taman Mayura Kota Mataram baik secara vertikal maupun horizontal. Bentuk komunikasi ritual dalam penelitian ini adalah komunikasi yang terjadi pada segala aktivitas dalam tahapan-tahapan ritual pada upacara tawur labuh gentuh di Taman Mayura Kota Mataram dari perencanaan sampai upacara berakhir, baik berupa kata-kata (verbal) dan gerakan-gerakan tertentu (nonverbal).

\section{PEMBAHASAN}

\section{Upacara Tawur Labuh Gentuh Di Taman Mayura Kota Mataram}

Secara etimologi upacara tawur labuh gentuh berasal dari kata upacara, tawur, labuh dan gentuh. Menurut Dharmita (2011:25) kata upacara berasal dari Bahasa Sanskerta yakni upa berarti sekeliling atau menunjuk segala dan cara berarti gerak atau aktivitas. Jadi upacara secara harfiah berarti yang berhubungan dengan gerakan atau cara, dengan kata lain gerakan kegiatan manusia untuk menghubungkan diri dengan Ida Sang Hyang Widhi Wasa. Kata tawur mengacu pada Keniten dan Gunarta (2005: 4-5) menyatakan tawur bentuk aktifnya adalah nawur yang berarti bayar. Kata tawur lalu mengalami perubahan bunyi menjadi tabur. Menurut Swastika (2013: 4) tawur merupakan bentuk korban suci yang ditujukan kehadapan Ida Sang Hyang Widhi Wasa dengan segala bentuk manifestasinya dan juga para bhuta kala dengan tujuan untuk membersihkan dan mengharmoniskan serta menyucikan kembali palemahan suatu wilayah atau bumi. Sedangkan kata labuh berarti jatuh dan gentuh berarti getaran. Jadi pengertian labuh gentuh adalah sesuatu yang jatuh atau terjadi baik itu bersifat sekala atau niskala yang menghasilkan getaran atau vibrasi yang dalam hal ini bersifat tidak baik. Upacara tawur labuh gentuh bertujuan untuk menetralisir vibrasi yang tidak baik dari suatu kejadian supaya menjadi vibrasi yang baik. 
Upacara tawur labuh gentuh yang dilaksanakan umat Hindu di Taman Mayura Kota Mataram merupakan salah satu bentuk upacara bhuta yajña dalam rangka tawur kesanga yang tingkatannya lebih besar daripada caru dengan tujuan marisudha gumi. Menurut Swastika (2013:14-15) bhuta yajña terdiri dari dua kata yaitu bhuta dan yajña. Bhuta akar katanya bhu yang berarti ada, jadi bhuta artinya diadakan atau diciptakan, sedangkan yajña akar katanya yaj yang berarti korban, yajña adalah korban suci. Dengan demikian bhuta yajña adalah persembahan atau korban suci yang ditujukan kepada para bhuta kala dengan harapan beliau tidak mengganggu sehingga alam ini menjadi harmonis.

Upacara tawur labuh gentuh dipimpin oleh sembilan Sulinggih Siwa Buddha yang ada di Lombok, kesembilan sulinggih yang memimpin upacara tersebut adalah sebagai berikut: (1) Pedanda Gde Oka Bajing dari Geria Sindu, (2) Pedanda Gde Nengah Gunung dari Geria Tohpati, (3) Pedanda Gde Nyoman Keniten dari Geria Sindu, (4) Pedanda Gde Nyoman Sebali Kenatan dari Geria Sweta, (5) Pedanda Gde Ketut Kertha Arsa dari Geria Pagesangan, (6) Pedanda Gde Made Oka Dharma dari Geria Buda Abian Tubuh, (7) Pedanda Gde Made Jelantik Gautama dari Geria Arong-Arong, (8) Pedanda Gde Putra Sanggya Geria Buda Abian Tubuh, (9) Pedanda Gde Made Jelantik Dwija Putra dari Geria Suranadi.

Bentuk Komunikasi Ritual dalam Upacara Tawur Labuh Gentuh

Bentuk komunikasi ritual pada penelitian ini adalah bentuk-bentuk hubungan komunikasi yang cenderung sering dilakukan dalam kehidupan sehari-hari. Dalam penelitian ini bentuk komunikasi yang dimaksudkan adalah bentuk atau wujud dari proses interaksi ataupun hubungan yang dilakukan oleh umat Hindu pada saat upacara tawur labuh gentuh di Taman Mayura Kota Mataram.

\section{Komunikasi Transenden}

Komunikasi transenden

(trancendental communication) adalah komunikasi antara manusia dengan Tuhan (Effendy, 2003:342). Pada pelaksanaan upacara tawur labuh gentuh di Taman Mayura Kota Mataram umat Hindu sudah melakukan komunikasi dengan kekuatan adikodrati. Umat melaksanakan persembahyangan bersama yang dipimpin oleh Pedanda Siwa dan Buda dengan media komunikasi berupa banten memohon keharmonisan bhuana alit dengan bhuana agung. Di dalam proses pelaksanaan upacara tawur labuh gentuh mengandung pesan yang ingin disampaikan menggunakan bentuk pesan komunikasi verbal dan nonverbal. Bentuk komunikasi verbal dalam hal ini adalah mantra-mantra suci yang diucapkan oleh pedanda sedangkan bentuk komunikasi nonverbalnya adalah gerakan mudra pedanda serta berupa banten yang dipersembahkan pada saat upacara. Mantramantra suci yang diucapkan oleh pedanda sebagai komunikasi verbal menjadi pengantar persembahan umat Hindu kepada kekuatan adikodrati di alam semesta ini. Upacara tawur labuh gentuh menggunakan media banten yang telah diatur sedemikian rupa sebagai komunikasi nonverbal.

\section{Komunikasi Sosial}

Komunikasi sosial mengisyaratakan bahwa komunikasi penting untuk membangun konsep diri, aktualisasi diri, kelangsungan hidup, memperoleh kebahagiaan, terhindar dari tekanan dan 
ketegangan, antara lain lewat komunikasi yang menghibur, dan memupuk hubungan dengan orang lain (Mulyana, 2012:5-6) Melalui pelaksanaan upacara tawur labuh gentuh di Taman Mayura terjalin komunikasi sosial yang baik sehingga mampu merangkul tokoh-tokoh umat Hindu yang berada di Nusa Tenggara Barat untuk berkomunikasi dalam forum rapat, baik dari sulinggih, pinandita, Parisada Hindu Dharma Indonesia, kelihan banjar maupun umat sedharma yang menjadi panitia pelaksana upacara. Semua komponen yang berasal dari berbagai latar belakang profesi berkumpul bersama untuk mebahas pelaksanaan upacara tawur labuh gentuh yang merupakan tawur agung tingkat provinsi.

Pada proses pelaksanaan upacara tawur labuh gentuh dari perencanaan sampai upacara berakhir sesungguhnya umat Hindu di Nusa Tenggara Barat menumbuhkan semangat kebersamaan. Pada saat saat rapat di Taman Mayura mencerminkan rasa solidaritas tinggi umat Hindu yang dilanjutkan pada pelaksanaan upacara sampai selesai. Pelaksanaan upacara tawur labuh gentuh dari perencanaan sampai upacara berakhir menjadi wadah komunikasi untuk mempererat persatuan dan rasa menyamabraya umat Hindu di Nusa Tenggara Barat. Semua tokoh-tokoh umat berkumpul untuk berkomunikasi menyamakan persepsi melaksanakan yajña supaya berjalan lancar demi kepentingan bersama.

Hal ini sesuai dengan teori tindakan komunikatif dari Jurgen Habermas, dalam teori tindakan komunikatif, Habermas menyatakan bahwa tindakan manusia yang paling dasar adalah tindakan komunikatif atau interaksi. Tujuan komunikasi adalah saling pengertian. Dalam tindakan komunikatif, pihak-pihak yang berbicara beranggapan bahwa mereka memaknai hal yang sama dengan ekspresi tertentu, bahwa apa yang mereka katakan adalah bisa dipahami pendengar, bahwa proposisi mereka adalah benar, bahwa masing-masing bersikap tulus dan siap menjalankan kewajiban demi pencapaian konsensus, dan bahwa mereka datang untuk memahami satu sama lain melalui proses dialog dimana mereka saling mendengarkan. Supaya komunikasi dapat berhasil, maka orang harus berbicara dengan jelas, benar, jujur dan tepat, sehingga hubungan antar manusia dapat berjalan dengan baik.

\section{Komunikasi Kelompok}

Komunikasi kelompok adalah komunikasi yang terjadi apabila jumlah pelaku komunikasi lebih dari tiga orang. Dalam komunikasi kelompok, komunikator relatif mengenal komunikan dan demikian juga antarkomunikan. Bentuk komunikasi kelompok adalah pertemuan atau rapat. Komunikasi kelompok pasti melibatkan komunikasi antarpribadi. Umpan balik dapat diterima dengan segera, menentukan penyampaian pesan berikutnya. Pesan di dalam komunikasi kelompok relatif lebih terstruktur, bersifat formal maupun informal. Komunikasi kelompok dapat terjadi di dalam kelompok dan juga antar kelompok (Vardiansyah, 2004:31). Ditegaskan lagi oleh Mulyana (2012:82) mengatakan bahwa kelompok adalah sekumpulan orang yag mempunyai tujuan bersama, yang berinteraksi satu sama lain untuk mencapai tujuan bersama, mengenal satu sama lainnya, dan memandang mereka sebagai bagian dari kelompok tersebut, meskipun setiap anggota mempunyai peran berbeda. Komunikasi 
kelompok biasanya merujuk pada komunikasi yang dilakukan kelompok kecil (small group communication), jadi bersifat tatap muka. Umpan balik dari seorang peserta dalam komunikasi kelompok masih bisa diidentifikasi dan ditanggapi langsung oleh peserta lainnya. Komunikasi kelompok dengan sendirinya melibatkan juga komunikasi antarpribadi.

Umat Hindu mengadakan rapat untuk merencanakan upacara tawur labuh gentuh merupakan bentuk komunikasi kelompok. pelaksanaan pecaruan tahunan yang mengambil tingkatan upacara tawur labuh gentuh di Taman Mayura Kota Mataram, merupakan program Parisada Hindu Dharma Indonesia Provinsi Nusa Tenggara Barat yang didukung oleh krama Pura Meru Cakranegara. Mencermati proses awal yang dimulai dengan mengadakan rapat panitia pelaksana menunjukkan upacara tawur labuh gentuh ini sudah terstruktur dengan baik. Melalui bentuk komunikasi kelompok terjadi proses komunikasi untuk menentukan panitia pelaksana dan tingkatan pecaruan yang akan dilaksanakan sesuai dengan kesepakatan bersama di dalam rapat.

$\mathrm{Hal}$ ini sesuai dengan teori tindakan komunikatif Jurgen Habermas yang menekankan tindakan komunikatif lebih berorientasi untuk mencapai pemahaman bersama (konsensus). Habermas mengatakan suatu interaksi adalah komunikatif jika pihakpihak terkait bisa mengoordinasikan rencana aksi secara konsensus, kesepakatan yang dicapai pada setiap titik selalu dievaluasi dalam kaitannya dengan pengakuan intersubjektif atas klaim validitas. Dalam tindakan komunikatif, pihak-pihak yang berbicara beranggapan bahwa mereka memaknai hal yang sama dengan ekspresi tertentu, bahwa apa yang mereka katakan adalah bisa dipahami pendengar, bahwa proposisi mereka adalah benar, bahwa masing-masing bersikap tulus dan siap menjalankan kewajiban demi pencapaian konsensus, dan bahwa mereka datang untuk memahami satu sama lain melalui proses dialog dimana mereka saling mendengarkan (Habermas dalam Culler, 1985:134).

\section{Komunikasi Antarpribadi}

Komunikasi antarpribadi (interpersonal communication) menurut Mulyana (2012:81) adalah komunikasi antara orang-orang secara tatap muka, yang memungkinkan setiap pesertanya menangkap reaksi orang lain secara langsung, baik secara verbal maupun nonverbal. Bentuk khusus komunikasi antarpribadi adalaah komunikasi diadik (dyadic communication) yang melibatkan hanya dua orang. Ciri-ciri komunikasi diadik adalah pihak-pihak yang berkomunikasi mengirim dan menerima pesan secara simultan dan spontan baik secara verbal maupun nonverbal.

Lebih lanjut dipertegas oleh Vardiansyah (2004:30-31) menyebutkan komunikasi antarpribadi adalah komunikasi yang terjadi dalam konteks satu komunikator dengan satu komunikan (komunikasi diadik: dua orang) atau satu komunikator dengan dua komunikan (komunikasi triadik: tiga orang). Komunikasi antarpribadi dapat berlangsung secara tatap muka atau menggunakan media komunikasi antarpribadi (nonmedia massa), seperti telepon. Dalam komunikasi antar pribadi, komunikator relatif cukup mengenal komunikan dan sebaliknya. Pesan dikirim dan diterima secara simultan dan spontan, relatif kurang terstruktur, demikian pula dengan umpan balik yang dapat diterima dengan segera. Dalam tataran antarpribadi, 
komunikasi berlangsung secara sirkuler, peran komunikator dan komunikan terus dipertukarkan, karenanya dikatakan bahwa kedudukan komunikator dan komunikan relatif setara. Proses ini lazim disebut dialog, walaupun dalam konteks tertentu dapat juga terjadi monolog, hanya satu pihak yang mendominasi percakapan. Efek komunikasi antarpribadi paling kuat diantara tataran komunikasi lainnya. Dalam komunikasi antarpribadi, komunikator dapat mempengaruhi langsung tingkah laku (efek konatif) dari komunikannya, memanfaatkan pesan verbal dan nonverbal, serta segera merubah atau menyesuaikan pesannya apabila didapat umpan balik negatif .

\section{Komunikasi Simbolik}

Salah satu kebutuhan pokok manusia, seperti dikatakan Susanne K. Langer, adalah kebutuhan simbolisasi atau penggunaan lambang. Manusia memang satu-satunya hewan yang menggunakan lambang dan itulah yang membedakan manusia dengan makhluk lainnya. Ernst Cassirer mengatakan bahwa keunggulan manusia atas makhluk lainnya adalah keistimewaan mereka sebagai animal symbolicum (Mulyana, 2012:92). Hal ini dipertegas oleh Cangara (2012:58) menyebutkan bahwa komunikasi dikatakan sebagai simbolik karena hampir semua pernyataan manusia baik yang ditujukan untuk kepentingan dirinya, maupun untuk kepentingan orang lain dinyatakan dalam bentuk simbol. Hubungan antara pihak-pihak yang ikut serta dalam proses komunikasi banyak ditentukan oleh simbol atau lambanglambang yang digunakan dalam berkomunikasi. Simbol merupakan hasil kreasi manusia dan sekaligus menunjukkan tingginya kualitas budaya manusia dalam berkomunikasi. Simbol dapat dinyatakan dalam bentuk bahasa lisan atau tertulis (verbal) maupun melalui isyarat-isyarat tertentu (nonverbal). Simbol membawa pernyataan dan diberi arti oleh penerima, karena itu memberi arti terhadap simbol yang dipakai dalam berkomunikasi bukanlah hal yang mudah.

Upacara tawur labuh gentuh di Taman Mayura Kota Mataram banyak sekali menggunakan simbol-simbol baik verbal maupun nonverbal. Upacara tawur labuh gentuh di Taman Mayura Kota Mataram menggunakan media banten yang telah diatur sedemikian rupa sebagai komunikasi nonverbal. Segala penjuru mata angin dipersembahkan banten berbeda-beda sesuai dengan petunjuk orang suci yang mengacu pada sumber sastra Hindu. Menurut Titib (2000:134) banten adalah persembahan suci yang dibuat dari sarana tertentu antara lain berupa bunga, buahbuahan, daun tertentu seperti sirih, dari makanan seperti nasi, lauk pauk dan jajan. Sarana yang sangat penting lainnya adalah air dan api. Upacara tawur labuh gentuh menggunakan sarana banten sebagi simbol komunikasi kepada kekuatan adikodrati. Simbol tersebut mempunyai makna yang disepakati bersama oleh umat Hindu. Hal ini sesuai dengan teori semiotika Charles Sander Pierce yang mengungkapkan simbol yang dalam hal ini adalah sarana banten pada upacara tawur labuh gentuh merupakan jenis tanda yang bersifat abriter dan konvensional sesuai kesepakatan sejumlah orang atau masyarakat.

Pada rangkaian upacara tawur labuh gentuh juga disertai pementasan tariantarian sebagai pendukung upacara yang mempunyai makna tersendiri. Tarian tersebut adalah Wayang Lemah, Tari Rejang 
Dewa dan Topeng Sidakarya yang dipentaskan secara bergantian. Setelah selesai pelaksanaan persembahyangan bersama umat Hindu mendapatkan rerajahan yamaraja, nasi dan tirta caru untuk dibawa pulang ke rumah masing-masing. Rerajahan Yamaraja sebagai simbol kekuatan adikodrati yang mengendalikan bhuta kala, dengan demikian umat Hindu berharap supaya para bhuta kala tidak mengganggu kehidupan manusia di dunia ini.

\section{PENUTUP}

\section{Simpulan}

Berdasarkan hasil penelitian dan pembahasan dapat disimpulkan bentuk komunikasi ritual dalam upacara tawur labuh gentuh di Taman Mayura Kota Mataram adalah sebagai berikut: (1) komunikasi transenden yakni komunikasi antara manusia dengan kekuatan adikodrati. Pada pelaksanaan upacara tawur labuh gentuh di Taman Mayura Kota Mataram umat Hindu melaksanakan persembahyangan bersama yang dipimpin oleh Pedanda Siwa dan Buda dengan media komunikasi berupa banten memohon keharmonisan bhuwana alit dengan bhuwana agung. Di dalam proses pelaksanaan upacara menggunakan bentuk pesan komunikasi verbal dan nonverbal. Bentuk komunikasi verbal dalam hal ini adalah mantra-mantra suci yang diucapkan oleh pedanda sedangkan bentuk komunikasi nonverbalnya adalah gerakan mudra pedanda serta berupa banten yang dipersembahkan pada saat upacara, (2) Komunikasi sosial yakni melalui pelaksanaan upacara tawur labuh gentuh di Taman Mayura terjalin komunikasi sosial yang baik sehingga mampu merangkul tokoh-tokoh umat Hindu yang berada di Nusa Tenggara Barat. Komunikasi sosial yang dilakukan umat
Hindu dengan mengadakan rapat merupakan bentuk komunikasi kelompok dan di dalamnya terjadi komunikasi antarpribadi, (3) komunikasi kelompok yang dimulai dengan krama pangempon Pura Meru mengadakan rapat di Bale Kambang Taman Mayura untuk membicarakan pecaruan yang biasa dilaksanakan setiap tahun pada sasih kesanga. Melalui bentuk komunikasi kelompok terjadi proses komunikasi dengan menggunakan bentuk pesan verbal dan nonverbal untuk menentukan panitia pelaksana dan tingkatan pecaruan yang akan dilaksanakan. Pada akhirnya sesuai dengan kesepakatan bersama di dalam rapat diputuskan melaksanakan upacara tawur labuh gentuh. Begitu juga pada saat persiapan sarana upacara, puncak upacara sampai berakhirnya upacara seluruh rangkaian upacara berjalan dengan baik berkat komunikasi yang efektif antar umat Hindu di Nusa Tenggara Barat, (4) komunikasi antarpribadi dalam hal ini otomatis terjadi dalam komunikasi kelompok. Masing-masing peserta rapat memiliki hak suara untuk mengusulkan tingkatan pecaruan yang akan dilaksanakan dan susunan kepanitian dalam upacara tawur labuh gentuh. Melalui komunikasi antar pribadi yang efektif karena ada ikatan emosi yang sama antar krama pangempon Pura Meru penentuan tingkatan pecaruan dan susunan kepanitiaan dapat berjalan lancar sesuai kesepakatan bersama. Komunikasi antar pribadi yang efektif dengan bentuk pesan verbal dan nonverbal dari umat Hindu di Nusa Tenggara Barat yang mengikuti seluruh rangkaian upacara tawur labuh gentuh berperan besar menyukseskan upacara tersebut, (5) komunikasi simbolik dapat dilihat pada setiap rangkaian upacara tawur labuh gentuh mulai dari upacara mapepada yang menyupat semua 
wewalungan; nyepat genah upacara yang membuat catus pata dan asta dala secara niskala; puncak upacara yang menggunakan berbagai jenis banten dan dipuput oleh sembilan Pedanda Siwa dan Budha; pementasan Wayang Lemah, Tari Rejang Dewa dan Tari Topeng Sidakarya; dan pada akhir upacara ada pembagian rerajahan Yamaraja, nasi caru dan tirta caru. Semua prosesi upacara tersebut menggunakan simbol-simbol dan terdapat bentuk pesan verbal dan nonverbal.

\section{DAFTAR PUSTAKA}

Culler Jonathan. 1983. On Deconstruction Theory and Criticism after Structuralism. London: Routledge.

Dharmita, I. P. M. S. B. D. 2011.Filsafat Rsigana Penciptaan Dunia-Alam Semesta. Denpasar: Pustaka Bali Post Effendy, Onong Uchjana. 2003. Ilmu, Teori dan Filsafat Komunikasi. Bandung: PT. Citra Aditya Bakti.

Habermas, Jurgen. 1979. What is Universal Pragmatics?, dalam JH Communication and the Evolution of Society. Boston: Beacon Press

Keniten, I. P. P. P. dan Gunarta. 2005. Tinjauan Tabuh Rah dan Judi. Surabaya: Paramita

Mulyana, Deddy. 2012. IImu Komunikasi Suatu Pengantar. Bandung: PT. Remaja Rosdakarya.

Sugiyono. 2014. Metode Penelitian Pendidikan Pendekatan (Kuantitatif, Kualitatif, dan R\&D), Bandung: Alfabeta.

Swastika, I K. P. 2013. Bhuta Yajña. Denpasar: Pustaka Bali Post.

Tim Prima Pena. 2006. Kamus IImiah Populer. Surabaya: Gitamedia Press.
Titib, I M. 2000. Teologi dan Simbol-Simbol dalam Agama Hindu. Surabaya: Paramita.

Vardiansyah, Dani. 2004. Pengantar IImu Komunikasi. Bogor: Ghalia Indonesia.

http://petrusandung.wordpress.com/2009/1 2/15/komunikasi-dalam-perspektifritual/

http://www.puragunungsalak.com/2010/03/ upacara-labuh-gentuh.html

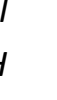

